\title{
RIGHTS, RECOGNITION, AND RECTIFICATION: CONSTITUTIONAL REMEDIES IN JOHNSON V. SAND
}

\author{
Barbara Billingsley
}

\section{INTRODUCTION}

Not long ago, the Supreme Court of Canada warned against narrowly interpreting section 15 of the Canadian Charter of Rights and Freedoms ${ }^{1}$ so as to bespeak a "thin and impoverished vision" of equality rights. ${ }^{2}$ Following this admonition, Canadian courts have rendered several decisions which arguably offer a large and liberal interpretation of section 15 and which give new life to the Charter's equality protection. ${ }^{3}$ In some recent cases, however, the courts have paired a liberal interpretation of the Charter's equality protection with a restrictive application of the Charter's remedy provisions, thereby issuing decisions which effectively return to a thin and impoverished view of the Charter's protective value when it comes to breaches of equality rights. ${ }^{4}$ Unfortunately, the Alberta Surrogate Court's ruling in Johnson v. Sand 5 is one

Canadian Charter of Rights and Freedoms, Part I of the Constitution Act, 1982, being Schedule B to the Canada Act 1982 (U.K.), 1982, c. 11. [hereinafter Charter]. Section 15(1) reads as follows:

Every individual is equal before and under the law and has the right to the equal protection and equal benefit of the law without discrimination and, in particular, without discrimination based on race, national or ethnic origin, colour, religion, sex, age or mental or physical disability.

Eldridge v. B.C., [1997] 3 S.C.R. 624 at para. 73.

Prominent examples include the Supreme Court of Canada's rulings in M. v. H., [1999] 2 S.C.R. 3; Vriend v. Alberta, [1998] 1 S.C.R. 493; and Corbiere v. Canada, [1999] 2 S.C.R. 203. Arguably, the Supreme Court has recently narrowed its approach to equality rights again in decisions such as Lovelace v. Ontario, [2000] 1 S.C.R. 950.

${ }_{4}$ See e.g. Walsh v. Bona, [2000] N.S.J. No. 173 (N.S.C.A.), online: QL (NSJ). In this case the Nova Scotia Court of Appeal found that the province's Matrimonial Property Act, R.S.N.S. 1989 , c. 275 violated the appellant's equality rights by discriminating against common law spouses. The Court issued a suspended declaration of invalidity, a remedy which did not personally benefit the appellant.

5 Johnson v. Sand, [2001] A.J. No. 390 (Alta. Q.B.), online: QL (AJ) [hereinafter Sand case or Sand]; supplementary reasons, [2001] A.J. No. 478 (Alta. Q.B.), online: QL (AJ) [hereinafter Sand supplement]. An appeal of both the main judgment and the supplementary reasons was filed, but the case was ultimately settled and the appeal did not proceed. such decision, a circumstance which is particularly unfortunate given the fact that the appeal of the case was discontinued in favour of settlement, so the Alberta Surrogate Court's ruling retains precedential value in Alberta's Charter jurisprudence.

\section{The SAND CASE}

The facts of Sand are uncomplicated and were not in dispute before the Court. Larry Sand died in April, 2000 due to injuries sustained when he was hit by a motor vehicle in March, 2000. Mr. Sand had been divorced from his wife since 1991. During their marriage, the Sands had two children and Mr. Sand was paying maintenance for both of these children at the time of his death. From May, 1994 until his death, Mr. Sand had been living with Brent Johnson in a same-sex relationship such that the two men "were an interdependent social and economic unit." At the time of his death, Mr. Sand did not have a will and, accordingly, the distribution of his estate fell under Alberta's Intestate Succession Act. ${ }^{7}$

The ISA provides a scheme for distributing a deceased's estate where no valid will exists: "In essence, the law creates a default will." ${ }^{8}$ Generally, where the intestate leaves a surviving spouse and children, the $I S A$ provides the first $\$ 40,000.00$ of the estate to the spouse and divides the remaining portion between the surviving spouse and the children. ${ }^{9}$ In the absence of a surviving spouse, the estate is distributed equally among the children. ${ }^{10}$ The $I S A$ does not define "spouse," but the "historical meaning of 'spouse' in the $I S A$ is a husband or wife, i.e., a legally married person." 11 This historical definition did not apply to

Sand, ibid. at para. 4.

Intestate Succession Act, R.S.A. 2000, c. I-10 [hereinafter ISA]. Sand, supra note 5 at para. 24.

ISA, supra note 7 at s. 3(1) and 3(3).

Ibid. at s. 4 .

1 Sand, supra note 5 at para. 25. See infra note 15, however, for a discussion of the decision in Bodnar v. Blacklock Estate, and its implications for the meaning of "spouse" in the ISA, supra note 7 . 
Brent Johnson because he was never legally married to Mr. Sand. ${ }^{12}$ Accordingly, Mr. Johnson brought an application for a declaration that the ISA violated his section 15 Charter right to equality by discriminating against him as a same-sex common-law spouse. Mr. Johnson also sought a corrective remedy which would entitle him to share as a spouse in the ISA's division of Mr. Sand's estate. Thus, the issues before the Alberta Surrogate Court were: (1) whether the ISA's failure to include a same-sex common-law spouse in its distribution scheme unjustifiably infringed $\mathrm{Mr}$. Johnson's equality rights under the Charter and (2) if so, what remedy should be provided for this infringement.

Mr. Johnson's application was heard by Justice Perras of the Surrogate Court of Alberta on 28 February 2001. In written reasons filed 2 April 2001, Perras J. concluded that the ISA did violate Mr. Johnson's equality rights by failing to include same-sex commonlaw spouses in the intestate distribution scheme and that this violation of section 15 could not be saved under section 1 of the Charter. ${ }^{13}$ As a remedy for this unjustifiable Charter breach, Perras J. issued a suspended declaration of invalidity. $\mathrm{He}$ found the impugned provisions of the $I S A$ to be invalid but suspended the effect of this declaration for nine months in order to give the Alberta legislature time to amend the law to remedy the constitutional defect. ${ }^{14}$ In addition, this ruling left the ISA provisions unchanged for nine months, thereby denying any specific relief to Mr. Johnson. Justice Perras expressly refused to rectify the ISA's invalidity by interpreting the statute in a way

12 Under Alberta law, Mr. Johnson and Mr. Sand could not legally be married. In fact, in order to eliminate any doubt regarding the ability of same-sex spouses to marry in Alberta, in March 2000 the province's Marriage Act, R.S.A. 2000, c. M-5 was amended to expressly define marriage as "a marriage between a man and a woman" and to include a provision stating that the Act, including the newly incorporated definition, operates notwithstanding sections 2, 7 and 15 of the Charter, supra note 1. See Marriage Act, R.S.A. 2000, c. M-5, s. 2, as am. by Marriage Amendment Act, S.A. 2000, c. 3. Query whether this amendment is constitutional from a division of powers standpoint, given that the federal government retains power over marriage under s. 91(26) of the Constitution Act, 1867 (U.K.), 30 \& 31 Vict., c. 3, reprinted in R.S.C. 1985, App. II, No. 5 and the provincial governments only have power to legislate regarding the solemnization of marriage under $s$. 92(12) of the same document. To date, this question has not been addressed by the courts and is beyond the purview of this paper.

13 See supra note 1 for the full text of s. 15(1) of the Charter. The entirety of s. 1 reads as follows:

The Canadian Charter of Rights and Freedoms guarantees the rights and freedoms set out in it subject only to such reasonable limits prescribed by law as can be demonstrably justified in a free and democratic society.

14 Sand, supra note 5 at para. 68. which would encompass same-sex common-law spouses within the ISA's distribution scheme and which would thereby have allowed Mr. Johnson to share in the Sand estate. Justice Perras could have achieved this result either by simply interpreting the word "spouse" to include same-sex common-law spouses or by expressly reading words into the statute to clearly cover same-sex common-law spouses. ${ }^{15}$

In considering whether to rectify the constitutional defect by reading words into the ISA, Perras J. acknowledged that the Supreme Court of Canada's ruling in Schachter v. Canada ${ }^{16}$ confirmed reading in as a valid remedy for a Charter breach. Nevertheless, Perras J. concluded that reading in the words "including a same-sex" before the word "spouse" in the ISA was not an appropriate remedy in the Sand case because this remedy would not satisfy the element of precision which Schachter established as one of the prerequisites for reading in: ${ }^{17}$

To simply read in the words pressed for does not solve the problem with precision, which the Supreme Court of Canada in Schachter (supra) indicated was one of the hallmarks of reading in. Simply reading in the words

15 Technically, these remedies are different in that the first remedy simply involves interpreting the statute in a manner consistent with the Charter while the second remedy involves putting words into the statute. On this technical basis, the first remedy is arguably more palatable because it does not involve the court in expressly drafting legislation. The effect of these remedies, however, is the same, and Perras J. certainly does not distinguish between the two. Any distinction between these remedies is not critical to my analysis of Perras J.'s comments. In any event, the remedy urged upon the court by Mr. Johnson's counsel was to read in the words "including a same-sex" before the word "spouse" in the impugned sections of the ISA, supra note 7. See Sand, supra note 5 at para. 55. Mr. Johnson's counsel relied on the finding of the Alberta Court of Queen's Bench in Bodnar v. Blacklock Estate, [2000] A.J. No. 1248 (Alta. Q.B.), online: QL (AJ) [hereinafter Bodnar] to conclude that common-law relationships had already been read in as part of the ISA reference to "spouse." In Bodnar, ibid. at para. 1, Belzil J. considered an application by an opposite-sex commonlaw spouse for an order entitling her to share in the deceased's estate under the ISA. Belzil J. found that the applicant and the deceased met all reasonable requirements for a common-law relationship because of the length of their conjugal cohabitation. He also held that no specific definition of the term "common law relationship" was necessary in order to read these words into the statute. Accordingly, Belzil J. ordered that the words "including a common law relationship, which is continuous up to the date of death of the intestate" should be read in wherever the word "spouse" was used in the Intestate Succession Act. The appellant in Bodnar was therefore deemed to be the surviving spouse of the intestate for the purposes of the statutory distribution.

16 Schachter v. Canada, [1992] 2 S.C.R. 679 [hereinafter Schachter].

17 Sand, supra note 5 at paras. 57-58. 
contended for before the word spouse where it appears in the ISA assumes that the court would then go on to define spouse beyond its historical legal meaning of husband and wife, to include common-law unions of either sex. In short, to simply read in the words contended for solves no problem and is of little or no effect in correcting the inconsistency.

The aspect of defining spouse to include, in essence, common-law unions no matter the sex is a daunting task.

Justice Perras then went on to note that the question of what qualifies as a common-law union for intestacy involves "pressing social policy issues"18 more suitable for the legislature to resolve. Justice Perras distinguished Miron v. Trudel ${ }^{19}$ and Grigg v. Berg Estate, ${ }^{20}$ two cases in which the courts read common-law spouses into challenged legislation, on the grounds that the courts in these cases read in definitions of common-law spouse which had already been adopted by the legislatures. Finally, noting that different definitions of "spouse" and "common-law spouse" exist under a variety of Alberta statutes, Perras J. concluded that: "In Alberta there is, to date, no consistency in defining spouse or a common-law spouse." ${ }^{21}$ Thus, it appears that Perras J. refused to read the required terms into the impugned legislation largely because he could not comfortably predict how the legislature might define these terms for the purposes of the ISA's distribution scheme.

Initially, Perras J. did not address the possibility of providing individual relief to $\mathrm{Mr}$. Johnson pursuant to section 24(1) of the Charter, which provides that a court may provide any appropriate and just remedy to an individual whose Charter rights have been violated. In supplementary reasons issued at the request of counsel, however, Perras J. considered and summarily dismissed this option: $:^{22}$

Having regard for the direction that there will be a temporary suspension of a declaration of invalidity for a period of nine months in so far as the impugned provisions of the Intestate Succession Act are concerned, it is not possible to fashion an individual remedy

\footnotetext{
18 Ibid. at para. 61 .

19 Miron v. Trudel, [1995] 2 S.C.R. 418 [hereinafter Miron]

20 Grigg v. Berg Estate (2000), 31 E.T.R. (2d) 214 (B.C. S.C.) [hereinafter Grigg].

Sand, supra note 5 at para. 64.

22 Sand supplement, supra note 5 at para. 2.
}

pursuant to s. 24 of the Charter and I decline to attempt to do so, vide Miron v. Trudel, [1995] 2 S.C.R. 419; Schachter v. Canada, [1992] 2 S.C.R. 679.

Thus, Perras J.'s ruling did not entitle Mr. Johnson to share in the Sand estate.

\section{ANALYSIS}

Obviously, Perras J.'s decision provided Mr. Johnson with a hollow victory: Mr. Johnson won the court's acknowledgement that his equality rights were unjustifiably infringed by the $I S A$ but still lost the right to share in the division of Mr. Sand's estate. My purpose in this commentary is to analyse Perras J.'s choice of constitutional remedy in light of his finding of a Charter breach. First, I argue that Perras J. erred in refusing to apply the remedy of reading in. Second, I argue that, having issued a suspended declaration of invalidity of the impugned provisions of the $I S A$, Perras $\mathrm{J}$. erred in refusing to grant an individual remedy to $\mathrm{Mr}$. Johnson. Finally, I submit that the unjust outcome of this case illustrates the need for courts to dispense with narrow and restrictive approaches to Charter remedies in favour of constructions which reflect a large and liberal approach to Charter rights.

Justice Perras correctly identified the Schachter case as Canada's leading decision on constitutional law remedies in general and on the reading in remedy in particular. In Schachter, the Supreme Court considered the appropriate remedy to be granted to a natural parent whose equality rights under section 15 of the Charter were breached by the provisions of the Unemployment Insurance Act, 1971. ${ }^{23}$ The Supreme Court found the challenged provisions of the Act to be unconstitutional because they failed to provide natural parents with the same economic benefits as adoptive parents. While the Supreme Court concluded that the appropriate remedy in Schachter was to issue a suspended declaration of invalidity, the Court expressly recognized that, in appropriate circumstances, reading in is a legitimate remedy under section 52 of the Constitution Act, $1982 .{ }^{24}$

The Supreme Court in Schachter held that the first step in choosing a remedy for a Charter breach is to determine the extent of the inconsistency between the impugned statute and the Charter: if the entirety of the statute or if the statute's purpose violates the Charter,

\footnotetext{
23 S.C. $1970-71-72$, c. 48.

24 Constitution Act, 1982, being Schedule B to the Canada Act 1982 (U.K.), 1982, c. 11.
} 
then the whole law must be struck down. On the other hand, if the constitutional defect is limited to an identifiable portion of the statute which does not significantly impact on the whole of the legislation, other remedial options, such as reading in, may be appropriate. The Supreme Court recognized that reading in is only the flip side of the severance remedy: severance allows a court to strike out words or phrases which make an otherwise valid law unconstitutional and reading in allows a court to add words or phrases to a statute necessary to make an otherwise invalid law constitutional. The Supreme Court noted, however, that when applying the reading in remedy, courts must be cautious to give due consideration to both the purposes of the Charter and the purposes of the legislature: ${ }^{25}$

Reading in should therefore be recognized as a legitimate remedy akin to severance and should be available under s. 52 in cases where it is an appropriate technique to fulfil the purposes of the Charter and at the same time minimize the interference of the court with the parts of legislation that do not themselves violate the Charter.

In light of these dual considerations, the Supreme Court concluded that reading in is an appropriate remedy only in the "clearest of cases."

According to the Supreme Court in Schachter, the "clearest of cases" are those in which the following criteria exist: (1) reading in can be done with sufficient precision; (2) reading in the excluded class is consistent with the legislative objective and is less intrusive to this objective than striking down the whole law; (3) reading in will not impose a substantial budgetary burden on the government; and (4) reading in will not significantly alter the non-offending portions of the legislation. ${ }^{27}$ In explaining the precision requirement, the Supreme Court stressed the importance of the relationship between severance and reading in, emphasizing that reading in is only appropriate where this remedy can be employed with the same degree of certainty typically associated with the remedy of severance: ${ }^{28}$

While reading in is the logical counterpart of severance, and serves the same purposes, there

\footnotetext{
Schachter, supra note 16 at 702

Ibid. at 718

27 For further discussion, description and explanation of these criteria, see $R$. v. Sharpe, [2001] 1 S.C.R. 45 at 113 [hereinafter Sharpe]; R. Khullar, "Vriend: Remedial Issues for Unremedied Discrimination” (1996) 7 N.J.C.L. 221 at 232-33 and P.W. Hogg, Constitutional Law of Canada, looseleaf (Scarborough: Carswell, 1997) at s. 37-12.

28 Schachter, supra note 16 at 705 .
}

is one important distinction between the two practices which must be kept in mind. In the case of severance, the inconsistent part of the statutory provision can be defined with some precision on the basis of the requirements of the Constitution. This will not always be so in the case of reading in. In some cases, the question of how the statute ought to be extended in order to comply with the Constitution cannot be answered with a sufficient degree of precision on the basis of constitutional analysis. In such a case, it is the legislature's role to fill in the gaps, not the court's.

Applying the Supreme Court's comments in Schachter to the Sand case, it appears that Perras J. erred in rejecting the reading in remedy on the basis that this remedy could not be employed with the requisite precision. With respect, Perras $\mathrm{J}$. interpreted the precision requirement in an unduly restrictive manner, essentially suggesting that remedial precision requires absolute certainty as to how the legislature would define the read in term. In fact, the Schachter requirement for remedial precision calls for only two things: first, that the terms to be read in and the place for their inclusion in the legislation are easily identifiable and second, that the terms to be read in have commonly understood meanings. The test really is whether the substance of the required read in is obvious: whether the court has "little choice as to how to cure the constitutional defect" 29 and whether the court can identify a "distinct provision" to rectify the constitutional problem. ${ }^{30}$

As previously noted, Perras J. relied on the Miron ${ }^{31}$ and Grigg $^{32}$ cases to illustrate his understanding of the remedial precision requirement. In each of these cases, the court was able to identify and define the terms to be read in with absolute certainty because the court simply adopted terms which had already been approved by the legislature. In those cases, the legislatures amended the challenged statutes after the respective cases had been commenced but before the courts had issued their judgments. Accordingly, the courts had considerable comfort in reading the amended definitions into the old statutes so as to benefit the parties before them. Obviously, these cases depict ideal circumstances for employing the remedy of reading in. I suggest, however, that Canadian jurisprudence does not limit the reading in remedy to such circumstances. First, no such

\footnotetext{
29 Hogg, supra note 27.

Sharpe, supra note 27 at 111.

Supra note 19.

Supra note 20.
} 
limitation is expressly stated in the Schachter decision. Second, since Schachter, Canadian courts have employed the reading in remedy on several occasions without the benefit of a preceding legislative amendment and, indeed, even in direct opposition to stated legislative intentions. ${ }^{33}$ Finally, restricting the use of the reading in remedy to circumstances where the court can simply mirror a legislative amendment would prevent the court from effectively and immediately protecting the Charter rights of individuals where the legislature refuses to act.

In Schachter, the Supreme Court referred to its rulings in Hunter v. Southam Inc. ${ }^{34}$ and in Rocket v. Royal College of Dental Surgeons of Ontario. ${ }^{35}$ In both of these cases the Supreme Court had found the relevant statutory schemes to be in breach of the Charter. Nevertheless, in both cases the Supreme Court also refused to apply the remedy of reading in because this remedy would have required the Court to essentially establish entirely new systems or regulations dealing with the matters in question. According to the Supreme Court in Schachter: ${ }^{36}$

In such cases, to read in would amount to making ad hoc choices from a variety of options, none of which was pointed to with sufficient precision by the interaction between the statute in question and the requirements of the Constitution. This is the task of the legislature, not the courts.

The Hunter and Rocket cases referred to by the Supreme Court in Schachter are much more helpful in defining the parameters of the precision requirement. These cases demonstrate that reading in should not be used where that remedy involves the court in essentially drafting a new regulatory system involving complicated policy choices. In such a circumstance, the court does not have a clear choice with respect to what words to read in - the court has many options to choose from and the choice made will impact the whole statutory

33 For example, see Vriend v. Alberta, supra note 3, where the Supreme Court of Canada read the words "sexual orientation" into Alberta's Human Rights, Citizenship and Multiculturalism Act, R.S.A. 2000, c. H-14 (formerly Individual's Rights Protection Act, R.S.A. 1980, c. I-2) notwithstanding the fact that the Alberta legislature had expressly decided not to include this term in the statute. See also infra note 46.

34 Hunter v. Southam Inc., [1984] 2 S.C.R. 145 [hereinafter Hunter].

35 Rocket v. Royal College of Dental Surgeons of Ontario, [1990] 2 S.C.R. 232 [hereinafter Rocket].

36 Schachter, supra note 16 at 707. scheme. ${ }^{37}$ This situation did not present itself, however, with respect to the constitutional breach identified in the Sand case.

The only viable option available to rectify the Charter problem in Sand was to redefine "spouse" either by judicial interpretation or by an express read in, so as to include same-sex common-law couples. This option would not have involved the court in rewriting complicated aspects of the distribution scheme recognized by the $I S A$. The court would simply have recognized that, in modern terms and for the purposes of Alberta's intestacy plan, "spouse" must include more than just an individual involved in a traditional marriage. $^{38}$ Of course, in order to arrive at this conclusion, the court has to understand the ISA scheme in a liberal, rather than a formalistic fashion.

On the liberal side, Perras J. characterized the ISA as a statute which creates a "default will." 39 More formalistically, however, Perras J. also opined early in his judgment that "the primary goal of the $I S A$ is to distribute a deceased's property in keeping with values considered basic in $1670 " 40$ which included distribution based "primarily on marriage bloodlines and generational concepts." ${ }^{41}$ With respect, this description of the statute's purpose undermines Perras J.'s own characterization of the statute's function of creating a default will. If the statute does operate as a default will, then we can assume that the distribution scheme in the $I S A$ attempts to reflect the distribution that a deceased would likely have chosen if the deceased had made a will. A reasonable assumption is that the deceased

37 Taylor v. Rossu (1998), 216 A.R. 348 (Alta. C.A.) [hereinafter Rossu], relied on by Perras J., is distinguishable on this same basis. In Rossu, the Alberta Court of Appeal considered a common-law spouse's application for spousal support. While agreeing that the legislation in question unjustifiably discriminated against common-law spouses, the Court of Appeal refused to read common-law spouses into the statute and instead issued a suspended declaration of invalidity. The court refused to employ the remedy of reading in because reading the necessary words into the impugned section would have had extensive repercussions for the entire statutory scheme and would have impacted on unrelated and unchallenged statutory provisions.

38 In this respect, the remedial precision criterion is closely linked to another of Schachter's criteria for reading in: namely, the significance of the remaining portion of the legislation. The test employed in Schachter regarding the latter criterion is whether the legislature, knowing that the statute would otherwise be held unconstitutional, would have passed the law including the read in provision. See Schachter, supra note 16 at $712-13$. I suggest that the Alberta legislature would have chosen to have an ISA including same-sex common-law spouses over no ISA at all.

39 Sand, supra note 5 at para. 24.

${ }_{40}$ Ibid.

${ }^{41} \quad$ Ibid 
would have wanted his or her property to be provided to the individuals having the greatest degree of longterm economic and emotional dependence on the deceased: a mate, then children, then other relatives. The concept of a "default will" does not necessarily link the distribution of an estate with marriage, particularly in the present day when many couples, regardless of gender considerations, reside in commonlaw relationships with their mates.

Section 15 of the ISA further demonstrates that emotional and economic dependence, and not marriage itself, is the cornerstone of the statute's distribution scheme. Section 15 expressly recognizes that a spouse who left the intestate and is living with someone else at the time of the intestate's death is not entitled to share in the deceased's estate. This provision prevents even an individual who was legally married to the deceased at the time of death from benefiting from the deceased's estate where that individual has transferred his or her emotional and economic dependence to someone else. Thus, marriage itself clearly is not the determining factor in the $I S A$ 's distribution scheme.

Although the remedy sought by Mr. Johnson's counsel was for the court to read in the words "including same-sex" before the word "spouse" in the $I S A$, Perras J. rested much of his decision on his concerns regarding a court-imposed expansion of the term "spouse" to include common-law spouses. In this regard, Perras J. was apparently unwilling to accept counsel's contention that the Alberta courts had already interpreted "spouse" in the $I S A$ as including commonlaw spouses. ${ }^{42}$ Arguably, Perras J. erred in dismissing counsel's contention that "spouse" had already been reinterpreted by the court to include common-law spouse. In any event, his points about whether the courts should reinterpret "spouse" in this fashion are troublesome. With respect to the definition of "common-law spouse," Perras J. correctly noted that Alberta legislation as a whole does not consistently define this term. Various statutes require different lengths of cohabitation before the cohabitants are recognized as common-law spouses. Once again, however, the fact that "common-law spouse" is defined in different ways for varying legislative purposes does not necessarily mean that this term fails to meet the Schachter requirement for remedial precision. Canadian jurisprudence does not require a term to have a single definition before it can be read into a statute. Further, the fact that a given statute may expressly restrict or expand the common definition of a word for the purpose of that statute does not necessarily make the word more difficult to understand in other contexts.

42 See the discussion of Bodnar, supra note 15.
Thus, while "common-law spouse" may be defined by the Alberta legislature in differing ways in order to meet the purposes of various statutes, the term retains a generally understood meaning which is sufficiently clear to allow the courts to determine whether an individual claiming to be a common-law spouse should be entitled to benefit as such under the ISA. Justice Perras inadvertently recognized this fact when he noted that at least two Alberta statutes, the Mental Health $A c t^{43}$ and the Municipal Government $A c t^{44}$ included common-law spouses without any reference to the length of cohabitation. ${ }^{45}$ Obviously the colloquial understanding of a common-law spouse being an unmarried but conjugal-like cohabitant is sufficiently clear for these statutes without the necessity of a statutorily defined length of cohabitation. The term "common-law spouse" certainly constitutes "a commonly used term with an easily discernible common sense meaning." 46

Finally, the legislature is not powerless to respond to any Charter decision or remedy laid down by the courts. Thus, if the Alberta legislature wants to limit the commonly understood definition of a common-law spouse for the purposes of the ISA, such action would not be thwarted by the court reading this term into the statute in the Sand case. Subject to the requirements of the Charter, the legislature is free to amend the distribution scheme in the $I S A$ in any manner it chooses at any time.

Overall, then, on the basis of the criteria set down in Schachter, the court in Sand should have read the required words into the $I S A$ to make the statute comply with section 15 of the Charter. The words to be read into the statute were ascertainable with sufficient precision. These words, "same-sex common-law spouse," are commonly understood and no intricate rewriting of the statute beyond the addition of these words was necessary. Reading in the excluded group or

43 Mental Health Act, R.S.A. 2000, c. M-13.

44 Municipal Government Act, R.S.A. 2000, c. M-26.

5 Supra note 5 at para. 66.

46 This was the characterization of the precision test applied by a majority of the Supreme Court of Canada when electing to read the term "sexual orientation" into Alberta's Individual's Rights Protection Act in Vriend v. Alberta, supra note 3 at 571 . See also Ferguson v. Armbrust, [2000] S.J. No. 312 (Sask. Q.B.), online: QL (SJ) and Re Nova Scotia (Birth Registration No. 1999-02-004200), [2001] N.S.J. No. 261 (N.S. S.C.), online: QL (NSJ), both recent decisions in which the courts interpreted the undefined statutory term "spouse" as including individuals in a common-law relationship or applied the remedy of reading in common-law spouses where the statute was found not to include same within its reference to "spouse." Neither court required any specialized definition of "common-law spouse" other than the general understanding that the term refers to someone in an unmarried conjugal relationship. 
adopting a definition of spouse to include this group would have been consistent with the legislative objective of creating a default will for intestacy situations. The remedy did not have any budgetary implications for the government because no public expenditure was required. Finally, the remedy would not have had a significant impact on the remaining portion of the legislation because, accepting the statutory purpose described above, the statute's overall distribution scheme would not have been altered.

\section{GRANTING AN INDIVIDUAL REMEDY IN CONJUNCTION WITH A SUSPENDED DECLARATION OF INVALIDITY}

If Perras J. had employed the remedy of reading in, Mr. Johnson would have been included within the ISA's court-imposed expanded definition of "spouse."Having decided instead to issue a suspended declaration of invalidity, however, Perras J. was then called upon to determine whether Mr. Johnson could still be brought within the statute's distribution scheme by virtue of the Court's power to grant an individual remedy under section 24(1) of the Charter. The appropriate individual remedy would have been an order entitling Mr. Johnson to be treated as a "spouse" under the ISA for the purpose of the distribution of Mr. Sand's estate notwithstanding the suspended declaration of invalidity.

As previously noted, Perras J. ultimately refused to provide Mr. Johnson with such an individual remedy, relying on the Supreme Court of Canada's rulings in Schachter and in Miron to summarily conclude that "it is not possible to fashion an individual remedy pursuant to s. 24 of the Charter" ${ }^{\prime 47}$ where a suspended declaration of invalidity has been issued. With respect, I submit that this is not the case. First, nothing in the express wording of section 52 or section 24 prohibits their conjunctive use. Second, neither Schachter nor Miron support this principle. Although an individual remedy was denied in each of these cases, this denial was based on the court's finding that such a remedy was inappropriate in the circumstances. Neither decision went so far as to expressly prohibit, in principle, the granting of an individual remedy in conjunction with a suspended declaration of invalidity where it is just to do so. In fact, Lamer C.J.C.'s statements in Schachter that a section 24 remedy will only "rarely" be available in conjunction with a section 52 remedy $^{48}$ imply that, in

47 Sand supplement, supra note 5 at para. 2.
48 Schachter, supra note 16 at 720. some limited circumstances, such a combined remedy can be appropriately rendered.

In Miron, a majority of the Supreme Court applied the remedy of reading in and therefore did not have to expressly rule on whether an individual remedy could be granted where a suspended declaration of invalidity had been issued. ${ }^{49}$ Nevertheless, in choosing between the reading in remedy and a suspended declaration of invalidity, McLachlin J. (as she then was) made the following comments regarding the possibility of using the latter remedy in conjunction with an individual remedy for the applicants: ${ }^{50}$

It is suggested that the Court could fashion a remedy for the appellants under s. 24(1) of the Charter ... Assuming the Court were inclined to grant the appellants an exemption from the 1980 legislation and insurance policy provisions, the question remains of how it could do so without creating further inequities between the appellants and others in their situation who have been denied benefits. To avoid this, any constitutional exemption would have to be extended to all similar families. This in turn would require formulation of general criteria of eligibility, thus involving the court in the very activity which would have led it to eschew "reading up" the 1980 statute in conformity with the terms legislated in 1990. Yet to deny such persons a remedy would be to perpetuate the effects of a discrimination which the Court has found to violate the Charter when the obvious remedy - the payment of the benefits that should have been paid - remains available.

It is clear that McLachlin J.'s comments do not bar the conjunctive use of a personal remedy and a suspended declaration of invalidity in all cases. Her comments simply reflect her view that, in the case before her, the simplest solution was to read the necessary words into the statute. Evidently her concern in the case before her was that a suspended declaration of invalidity coupled with an individual remedy for the applicant would necessarily open the floodgates for individual remedies being sought by other persons affected by the legislation before the term of suspension was up. Thus, it appears that the only relevant principle established by Canadian jurisprudence is that a personal remedy should only be used in conjunction with a suspended declaration of invalidity in appropriate

49 The dissenting judges, having found no Charter breach, did not comment on appropriate or available remedial options.

so Miron, supra note 19 at 509-10. 
circumstances. ${ }^{51}$ I suggest that Mr. Johnson's situation in Sand fulfilled this requirement.

Moreover, apart from meeting the requirements established by the case law, combining an individual remedy with a suspended declaration of invalidity meets objective standards of justice and the overall purposes of the Charter. Justice demands that individuals who are wrongly treated by the state and who prove this mistreatment in a court of law be entitled to compensation or a rectification of that wrong. The Charter guarantees individuals' fundamental freedoms and rights, including the right to equal treatment and benefit of the law. Justice is not achieved and rights are not effectively guaranteed if individuals who successfully establish that their Charter rights have been denied are not given any personal, tangible benefit of such findings.

As noted by Perras J., Mr. Johnson cohabited with Mr. Sand in an economically and emotionally dependent relationship for approximately six years prior to Mr. Sand's death. Surely this relationship would qualify as a common-law union even under the most conservative definition. One can reasonably assume that Mr. Johnson would fall within any definition constructed by the legislature to remedy the constitutional breach. Mr. Johnson was not in a position to wait out the nine month period to see how the legislature would rectify the Charter breach because the legislative amendment almost certainly would not operate retroactively and the Sand estate would probably be dispensed by that time. Further, the floodgates concern which apparently influenced McLachlin J.'s comments in Miron simply did not arise in Mr. Johnson's case because statistically few people would be expected to be in a position to seek benefits as a same-sex common-law spouse under the ISA during the nine month period of suspension. Thus, having decided in favour of a suspended declaration of invalidity, the Court could have and should have ensured a satisfactory personal remedy for Mr. Johnson. As noted by one reputable constitutional law commentator: ${ }^{52}$

When delaying declarations of invalidity, courts should take steps to prevent irreparable

51 In fact, some commentators argue that Canadian courts have established, and certainly should establish a practice of ensuring that a litigant who is successful in bringing a constitutional challenge receives personal relief from the unconstitutional law where a suspended declaration of invalidity is issued. See $e . g$. K. Roach, Constitutional Remedies in Canada, looseleaf (Aurora, Ontario: Canada Law Book., 1994) at paras. $14.1810-14.1859$ and the cases referred to therein.

52 Ibid. at para. 14.1768. harm to individuals whose rights are violated while also giving governments a realistic time to devise new, constitutionally adequate structures.

\section{THE NEED FOR A “CONSTITUTIONAL INCLUSION” REMEDY}

To this point, my comments have focussed on the legal aspects of Perras J.'s choice of remedy in the Sand case. These legal issues are born, however, from a more fundamental problem with the Sand case: namely, that the result of the case is unjust. The notion that the ISA's discriminatory effect on Mr. Johnson should be recognized but not rectified is unfair and inconsistent with the spirit and intent of the Charter. In this case, the court was not justified in deferring to the legislature to rectify the constitutional wrong because a legislative amendment is unlikely to benefit Mr. Johnson even if it benefits other same-sex common-law spouses in the future.

Early in his judgment, Perras J. noted that the Charter "paved the way for the courts ... to grapple from time to time with vexing societal issues as guardians or trustees of new constitutional rights for individual citizens." ${ }^{53}$ This description of the court's role under the Charter should be applied not only to the court's duty to interpret the Charter's substantive rights but also to the court's obligation to construct appropriate remedies for Charter breaches. The Charter does indeed mandate the courts to be the guardians of constitutional rights for individual citizens. It is a poor guardian, however, who points to and recognizes existing danger, takes steps to prevent future harm from ensuing, but does nothing to forestall harm that is already occurring.

The Supreme Court of Canada's decision in Schachter is nearly a decade old. As illustrated by Perras J.'s ruling in Sand, the Schachter criteria for reading in are easily subject to misinterpretation and misapplication as the courts struggle to give life to Charter rights in the face of new and challenging social issues. Accordingly, Canadian courts need to clarify and expand the remedial options available for Charter breaches. Most obviously, there is a need for the Supreme Court of Canada, in a binding judgment, to revisit and clarify its comments in Schachter with respect to the criteria of remedial precision. In particular, the Supreme Court must restate the relationship between this element and the need for some degree of legislative deference. To avoid future

53 Sand, supra note 5 at para. 10. 
misunderstandings, it is also important that the Supreme Court expressly state that Schachter should not be interpreted as prohibiting the conjunctive use of section 52 and section 24 remedies. Finally, if section 15 is to be applied in a manner which does not bespeak a "thin and impoverished" view of equality rights, Canadian courts must correspondingly expand the selection of remedies available under sections 52 and 24 for equality breaches, particularly where the breaches take the form of under-inclusive legislation. One option would be for the courts to formally recognize a remedy of "constitutional inclusion": essentially allowing applicants to personally benefit where the court suspends a declaration of invalidity for under-inclusive legislation. Alternatively, the courts could establish the remedy of a "temporary read in," where words would be read into a statute or included as part of statutory interpretation only for the duration of a suspended declaration of invalidity. This temporary read in would not unduly tread on the legislature's role because the read in would not operate on a permanent basis. Nevertheless, this option would still provide relief to individuals whose rights would otherwise remain violated during the suspension period. ${ }^{54}$

\section{CONCLUSION}

The decision in Sand illustrates the ongoing challenge faced by Canadian courts in attempting to fashion appropriate remedies for legislative breaches of the Charter's equality protections. The courts have been encouraged to give a liberal interpretation and application of the Charter's equality provision. At the same time, however, the Courts have been increasingly criticized for becoming too activist in applying the Charter and thereby usurping the role of elected legislators. The latter criticisms may be responsible for the tentative approach which some courts, such as the Alberta Surrogate Court in Sand, now appear to be taking to Charter remedies. However, Canadian jurisprudence cannot be allowed to develop with broadly interpreted Charter equality rights alongside constrained Charter remedies. Permitting the law to develop along these lines reduces the practical effect of Charter rights. This approach prevents individuals,

54 Another option would be for the legislatures to give retroactive effect to any statutory changes made in response to a temporary declaration of invalidity. While the courts could recommend such action, the courts have no power to mandate this retroactive response, so this remedial option would be entirely up to the legislatures to grant. Further, this remedy would not offer a very practical solution to an individual whose rights have been violated since that individual might have to wait months for the legislative response to take effect. In a case such as Sand for example, by the time the legislative response occurs the estate in question might well have been dissipated. such as Mr. Johnson, from obtaining justice and, in the end, results in a thin and impoverished application of the Charter's equality rights.

\section{Barbara Billingsley}

Faculty of Law, University of Alberta. 